\title{
An Overview of Systematic Reviews of the Role of Vitamin D on Inflammation in Patients with Diabetes and the Potentiality of Its Application on Diabetic Patients with COVID-19
}

\author{
Christiano Argano ${ }^{1}$ (D), Raffaella Mallaci Bocchio ${ }^{1}$, Marika Lo Monaco ${ }^{1}$, Salvatore Scibetta ${ }^{1}$, Giuseppe Natoli ${ }^{1}$ (D), \\ Attilio Cavezzi ${ }^{2}$ (D) Emidio Troiani ${ }^{3}(\mathbb{D})$ and Salvatore Corrao ${ }^{1,4, *(D)}$
}

check for updates

Citation: Argano, C.; Mallaci Bocchio, R.; Lo Monaco, M.; Scibetta, S.; Natoli, G.; Cavezzi, A.; Troiani, E.; Corrao, S. An Overview of Systematic Reviews of the Role of Vitamin D on Inflammation in Patients with Diabetes and the Potentiality of Its Application on Diabetic Patients with COVID-19. Int. J. Mol. Sci. 2022, 23, 2873. https:// doi.org/10.3390/ijms23052873

Academic Editors: Francesca Silvagno and Loredana Bergandi

Received: 27 December 2021 Accepted: 25 February 2022 Published: 6 March 2022

Publisher's Note: MDPI stays neutral with regard to jurisdictional claims in published maps and institutional affiliations.

Copyright: (c) 2022 by the authors Licensee MDPI, Basel, Switzerland. This article is an open access article distributed under the terms and conditions of the Creative Commons Attribution (CC BY) license (https:// creativecommons.org/licenses/by/ $4.0 /)$
1 Department of Internal Medicine, National Relevance and High Specialization Hospital Trust ARNAS Civico, Di Cristina, Benfratelli, 90127 Palermo, Italy; chargano@yahoo.it (C.A.); raffaellamallacibocchio@gmail.com (R.M.B.); marika.lomonaco@hotmail.it (M.L.M.); salvusxyz@gmail.com (S.S.); peppenatoli@gmail.com (G.N.)

2 Eurocenter Venalinfa, 63074 San Benedetto del Tronto, Italy; info@cavezzi.it

3 Cardiology Unit, State Hospital, Social Security Institute, 20, 47893 Cailungo, San Marino; emidio.troiani@iss.sm

4 Department of Health Promotion Sciences, Maternal and Infant Care, Internal Medicine and Medical Specialties [PROMISE], University of Palermo, 90127 Palermo, Italy

* Correspondence: s.corrao@tiscali.it or salvatore.corrao@unipa.it; Tel.: +39-091-655-2065; Fax: +39-091-666-3167

\begin{abstract}
Almost two years have passed since the outbreak reported for the first time in Wuhan of coronavirus disease 2019 (COVID-19), due to severe acute respiratory syndrome (SARS)-CoV-2 coronavirus, rapidly evolved into a pandemic. This infectious disease has stressed global health care systems. The mortality rate is higher, particularly in elderly population and in patients with comorbidities such as hypertension, diabetes mellitus, cardiovascular disease, chronic lung disease, chronic renal disease, and malignancy. Among them, subjects with diabetes have a high risk of developing severe form of COVID-19 and show increased mortality. How diabetes contributes to COVID-19 severity remains unclear. It has been hypothesized that it may be correlated with the effects of hyperglycemia on systemic inflammatory responses and immune system dysfunction. Vitamin D (VD) is a modulator of immune-response. Data from literature showed that vitamin D deficiency in COVID-19 patients increases COVID-19 severity, likely because of its negative impact on immune and inflammatory responses. Therefore, the use of vitamin D might play a role in some aspects of the infection, particularly the inflammatory state and the immune system function of patients. Moreover, a piece of evidence highlighted a link among vitamin D deficiency, obesity and diabetes, all factors associated with COVID-19 severity. Given this background, we performed an overview of the systematic reviews to assess the association between vitamin D supplementation and inflammatory markers in patients with diabetes; furthermore, vitamin D's possible role in COVID-19 patients was assessed as well. Three databases, namely MEDLINE, PubMed Central and the Cochrane Library of Systematic Reviews, were reviewed to retrieve the pertinent data. The aim of this review is to provide insight into the recent advances about the molecular basis of the relationship between vitamin D, immune response, inflammation, diabetes and COVID-19.
\end{abstract}

Keywords: vitamin D; diabetes; COVID-19; overview; systematic review; immune system; inflammation; cytokines

\section{Introduction}

In late December 2019, the first pneumonia cases caused by severe acute respiratory syndrome coronavirus 2 (SARS-CoV-2) occurred [1]. By 11 March 2020, the WHO (World Health Organization) had declared the COVID-19 outbreak a global pandemic [2]. Up to 1 February 2022, 378,716,963 cases and 5,675,536 deaths were reported across the world [3]. 
This disease includes asymptomatic forms and different clinical manifestations [4]. Because of the rapid spread and high mortality rate of COVID-19, major efforts have been made to evaluate the possible risk factors affecting the progression of the disease in COVID-19 patients [5]. Elderly subjects and patients with comorbidities, such as diabetes mellitus (DM), hypertension, cardiovascular disease, chronic obstructive pulmonary disease and chronic renal insufficiency, are more likely to suffer from severe COVID-19, showing a higher mortality rate [6-10]. Overall, DM represents one of the most relevant chronic diseases that impacts hospitalization and mortality rates, with relevant economic repercussions on health care systems. It has been estimated that, in 2019, the prevalence of DM among adults was 463 million worldwide [11]. This disease represents the second most-frequent comorbidity in subjects affected by severe COVID-19 infection, after hypertension [12]. Different studies highlighted that DM is associated with disease severity, poor prognosis and mortality among COVID-19 patients [13-15]. However, systemic inflammatory response, increased coagulation activity, immune response impairment and direct pancreatic damage by SARS-CoV-2 might underpin the association between diabetes and COVID-19 $[13,16,17]$. It was demonstrated that elevated levels of pro-inflammatory cytokines were present in patients with severe COVID-19 and DM [18]. Moreover, a higher expression of ACE2 in human lung tissue has been associated with DM and its related treatments, which might increase sensitivity to SARS-CoV-2 infections [19]. Lastly, the level of glycated dysfunctional hemoglobin may contribute to the hypoxia in COVID-19 patients, most often those who are anemic, at later stages [20]. Therefore, it could be hypothesized that the combination of SARS-CoV-2 infection and DM might represent a negative condition that tends to complicate the course of the disease [21].

Vitamin D is a well-known hormone with principal effect on bone health, but different data has shown the extra-skeletal activities of vitamin D, such as the anti-inflammatory, antioxidant and immunomodulatory ones [22]. Many observational and epidemiological studies have suggested an association between vitamin D insufficiency and the incidence of type 1 and type 2 DM [23-26]. Furthermore, an intake of high monthly doses of vitamin $\mathrm{D}$ proved efficacious in reducing c-reactive protein (CRP) levels.

In fact, COVID-19 is characterized by high levels of inflammatory markers, including CRP, and increased levels of inflammatory cytokines and chemokines [27,28]. Given this background, we conducted an overview of the available systematic reviews to summarize the current knowledge and evidence about the role of vitamin D on the inflammatory process in patients affected by DM. Moreover, based on literature data, we aimed to indicate the possible role of vitamin D supplementation in the setting of patients affected by COVID-19.

\section{Materials and Methods}

\subsection{Eligibility Criteria}

All the meta-analyses and systematic reviews (SRs) regarding the association between vitamin D supplementation and inflammatory markers in patients with diabetes were eligible for this review.

\subsection{Search Methods}

On 13 September 2021, at 22:00 p.m. (GMT-5, Bethesta, MD, USA), a literature search was performed within the database of MEDLINE, PubMed Central and the Cochrane Library of Systematic Reviews (CLSR); the following search strings were used: ("vitamin D" [MeSH Terms] OR "vitamin D" [All Fields] OR “ergocalciferols" [MeSH Terms] OR "ergocalciferols" [All Fields] OR ("ergocalciferols "[MeSH Terms] OR" ergocalciferols "[All Fields] OR" ergocalciferol "[All Fields]) OR ("cholecalciferol "[MeSH Terms] OR" cholecalciferol "[All Fields] OR" cholecalciferols "[All Fields] OR" colecalciferol "[All Fields]) OR ("calcitriol "[MeSH Terms] OR" calcitriol "[All Fields] OR" calcitriols "[All Fields])) AND ("inflammation "[MeSH Terms] OR" inflammation "[All Fields] OR "inflammations" [All Fields] OR "inflammations" [All Fields] OR ("inflammatories" [All Fields] OR "inflamma- 
tory" [All Fields]) OR "TNF" [All Fields] OR ("interleukine" [All Fields] OR "interleukines" [All Fields] OR "interleukins" [MeSH Terms] OR "interleukins" [All Fi elds] OR “interleukin" [All Fields]) OR ("cytokin" [All Fields] OR "cytokine s" [All Fields] OR "cytokines" [MeSH Terms] OR "cytokines" [All Fields] OR "cytokine" [ All Fields] OR "cytokinic" [All Fields] OR "cytokins" [All Fields]).

\subsection{Study Selection}

Two authors (RMB and MLM) independently reviewed the titles, abstracts and full texts of the retrieved articles, to determine their potential inclusion using the eligibility criteria. Any disagreement was resolved by discussion with a third author (SC), and, when only limited information was available, the authors of the study were contacted to request the full text or further details.

\subsection{Data Extraction, Coding and Analysis}

Two authors (RMB and MLM) collected data from all the included articles using a pre-tested form and individuated duplicates and prepared the flow-chart of the excluded and included studies. SC and CA independently verified the entire process (Figure 1).

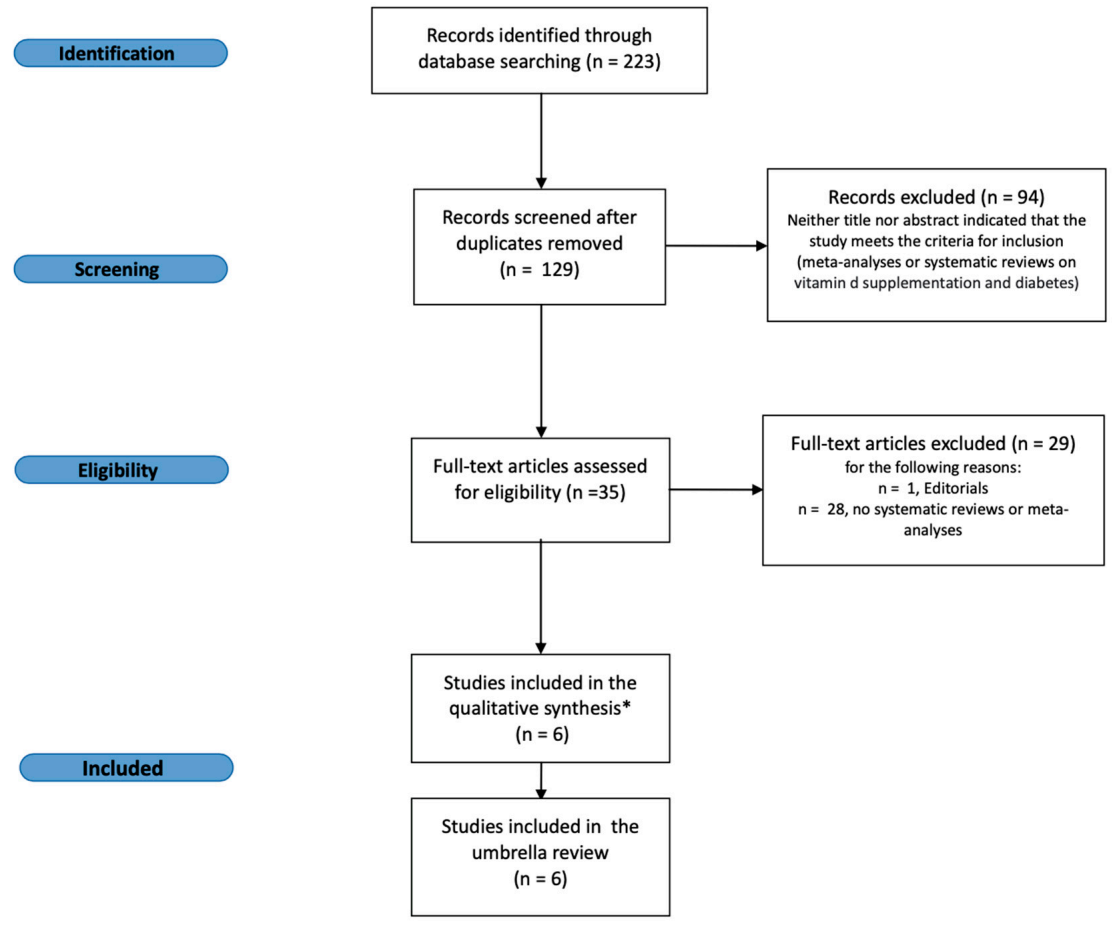

AMSTAR (Assessment of multiple systematic reviews) is the tool used for the qualitative analysis (see the text for more explanation)

Figure 1. Flow diagram of the study selection process.

\subsection{Quality Assessment of the Included Systematic Reviews}

Two authors (RMB, MLM) assessed the quality of the included SRs by means of AMSTAR (a measurement tool to checklist assess systematic reviews), which is a validated tool to assess the methodological quality of SRs. It includes 11 domains, such as the a priori protocol documentation, scientific quality and risk-assessment publication bias. Based on AMSTAR evaluations, we ordered the derived scores into tertiles and classified the methodological quality of each review in three categories: "high" (8-11 points out of 11), "moderate" (4-7 points) and "low" (3 or fewer points). (Table 1). 
Table 1. AMSTAR assessment for each systematic review regarding the association between vitamin D supplementation and inflammatory markers in patients with DM. Colors refer to scores: Green refers to "high scores" (8-11 points) and yellow to "moderate" (4-7 points). No systematic review had a "low" (<3 points) evaluation.

\begin{tabular}{|l|l|c|c|c|}
\hline & & High & Moderate & Low \\
\hline \multirow{6}{*}{ Vitamin D } & Omid Asbaghi (2019) [29] & $\bigcirc$ & $\bigcirc$ & $\bigcirc$ \\
& Sheila A. FisherID (2019) [30] & $\bigcirc$ & $\bigcirc$ & $\bigcirc$ \\
& Yanting Yu (2017) [31] & $\bigcirc$ & $\bigcirc$ & $\bigcirc$ \\
& Mohsen Mazidi (2018) [32] & $\bigcirc$ & $\bigcirc$ & $\bigcirc$ \\
& Tari Agbalalah (2017) [33] & $\bigcirc$ & $\bigcirc$ & $\bigcirc$ \\
& Neng Chen (2014) [34] & $\bigcirc$ & $\bigcirc$ & $\bigcirc$ \\
\hline
\end{tabular}

\section{Results}

The data of patients with DM were extracted and tabulated according to the result of each trial. Figure 1 shows the flow diagram of the study selection process. To ensure the highest data recruitment possible, initially we searched all the papers regarding vitamin D and cytokines; thereafter we extracted data about the patients with diabetes. The search strings we used permitted us to retrieve 223 bibliographic citations. These were screened, and 129 papers fit the eligibility criteria. Then, ninety-four studies were excluded because they were duplicates, six papers were removed because they were not systematic reviews or meta-analysis and twenty-nine articles were not taken into consideration as they were not pertinent to the aim of our overview. Thus, we finally identified six relevant papers, which were investigated for the details that pertain to this overview of the SRs. Table 1 shows the summary of the AMSTAR assessment. No SR regarding the vitamin D had low-quality results. Hence, we extracted each randomized clinical trials including patients with diabetes from every systematic review. The data from each randomized clinical data are reported in Table 2.

The SRs that have been taken into consideration were heterogenous in different aspects: patient characteristics, type of treatment, end-points and measured variables. However, this heterogeneity enriched the final analysis. Six SRs were included, with a follow-up duration between six and fifty-two weeks. Both patients with diabetes type 1 and type 2 were represented. The vitamin $\mathrm{D}$ doses used in these studies were widely variable. Three out of six SRs demonstrated a clear efficacy of the supplementation as to CRP reduction; one SR showed a statistically significant reduction of interleukin-6 (IL6) with vitamin D intake. Table 2 shows the various dosages used in each study. In their systematic review, Asbaghi et al., analyzing the only randomized clinical trial including subjects with type 2 diabetes, showed that 50,000 IU/week of vitamin D determined a reduction of serum CRP concentrations $(-1.19 \mu \mathrm{g} / \mathrm{mL} \pm 0.25)$; similarly, Chen and colleagues found that $1000 \mathrm{IU} /$ day decreased CPR levels [CPR $-0.40(-1.12,0.31]$. According to Yanting Yu et al., the vitamin $\mathrm{D}$ supplementation significantly decreased the hs-CRP level by an average of $0.45 \mu \mathrm{g} / \mathrm{mL}[p=0.005]$, particularly using a daily dose $\leq 4000$ IU with a supplementation time $>12$ weeks $[p=0.008]$. On the contrary, these authors showed no impact of the supplementation on TNF- $\alpha$ and IL-6 concentrations. On the other hand, Mazidi et al. showed that vitamin D supplementation had no impact on CRP, IL-10 and TNF- $\alpha$, whereas IL6 serum levels were detrimentally and significantly increased by the administration of vitamin D [0.67 pg/mL)]. Agbalalah and colleagues reported that, in patients with type 2 DM, a single-dose administration of 100,000 IU of vitamin D2 resulted, after 8 weeks, in a significant improvement of endothelial function, measured by flow-mediated dilation (FMD) [increase of $2.35 \pm 3.12 \%$ in FMD from a baseline of $6.38 \pm 4.31 \%(p=0.048)$ ] According to Fisher et al., in patients with type 1 diabetes, different doses of vitamin $\mathrm{D}$ caused a higher proportion of $\mathrm{T}$ regulatory cells in comparison with controls $[+6.4 \%$ (DS $0.8 \%$ ) of CD $4+C D 25+C D 127,+4.55 \% \pm 1.5 \%$ of CD $4+C D 25+F o x p 3+,+22.2 \pm 47.2 \%$ of CD4+CD25hi FoxP3+CD127low in CD4+ cells, respectively]. 
Table 2. Clinical trial data extracted for each meta-analysis reporting vitamin D supplementation in patients with diabetes.

\begin{tabular}{|c|c|c|c|c|c|c|c|}
\hline \multicolumn{8}{|c|}{ Clinical Trial Data Extracted for Each Meta-Analysis Reporting Vitamin D Supplementation in Patients with Diabetes } \\
\hline Meta-Analysis & Study & Sample Size & Population & Posology & $\begin{array}{c}\text { Intervention } \\
\text { Duration Range }\end{array}$ & Endpoint & Efficacy \\
\hline $\begin{array}{l}\text { Omid Asbaghi } \\
\text { (2020) [29] }\end{array}$ & Tabesh 2014 & 59 & Patients with type 2 diabetes mellitus & $\begin{array}{l}1000 \mathrm{mg} / \text { day Ca carbonate + } \\
50,000 \mathrm{IU} / \text { wk Vitamin D3 }\end{array}$ & 8 weeks & $\begin{array}{l}\text { CRP } \\
\text { IL-6 } \\
\text { TNF- } \alpha\end{array}$ & $\begin{array}{l}\text { We found a beneficial effect of } \\
\text { vitamin D-calcium } \\
\text { co-supplementation on serum } \\
\text { CRP concentrations while } \\
\text { there was no effect on IL- } 6 \\
\text { and TNF- } \alpha\end{array}$ \\
\hline \multirow{3}{*}{$\begin{array}{l}\text { Sheila A. Fisher } \\
\text { (2019) [30] }\end{array}$} & Bogdanou 2017 & 39 & $\begin{array}{l}\text { Patients with recent onset of } \\
>2 \text { months or chronic type } 1 \text { diabetes }\end{array}$ & $\begin{array}{l}4000 \mathrm{IU} / \text { day Vitamin D3 for } \\
\text { three months } \\
(120,000 \mathrm{IU} / \text { monthly })\end{array}$ & 6,12 weeks & $\begin{array}{l}\text { CD4+CD25+ } \\
\text { CD127 }\end{array}$ & \multirow{3}{*}{$\begin{array}{l}\text { Vitamin D improves the } \\
\text { absolute T regulatory cells } \\
\text { numbers and phenotypes in } \\
\text { patients with diabetes }\end{array}$} \\
\hline & Gabbay 2012 & 38 & $\begin{array}{l}\text { Patients with a new diagnosis of type } \\
1 \text { diabetes (T1DM) }\end{array}$ & $\begin{array}{l}2000 \text { IU/day Vitamin D3 for } \\
18 \text { months (60,000 IU monthly) }\end{array}$ & $6,12,18$ months & $\begin{array}{l}\text { CD4+CD25+ Foxp3+ in } \\
\text { Peripheral blood }\end{array}$ & \\
\hline & Treiber 2015 & 30 & $\begin{array}{l}\text { Young patients with new-onset } \\
\text { type } 1 \text { diabetes }\end{array}$ & $\begin{array}{l}70 \mathrm{IU} / \mathrm{kg} / \text { day Vitamin D3, } \\
\text { weekly for } 12 \text { months } \\
\text { (loading dose } 140 \mathrm{IU} / \mathrm{kg} / \text { day } \\
\text { for } 1 \text { month) (4200 IU for one } \\
\text { month then } 2100 \mathrm{IU} \text { monthly) }\end{array}$ & $3,6,12$ months & $\begin{array}{l}\text { CD4+CD25hi FoxP3+ } \\
\text { CD127low in CD4+ cells }\end{array}$ & \\
\hline \multirow{13}{*}{$\begin{array}{l}\text { Yanting Yu } \\
\text { (2018) [31] }\end{array}$} & Breslavsky 2013 & 47 & Patients with type 2 diabetes mellitus & 1000 IU/day Vitamin D3 & 52 weeks & \multirow{13}{*}{$\begin{array}{l}\text { CRP } \\
\text { TNF- } \alpha \\
\text { IL-6 }\end{array}$} & \multirow{13}{*}{$\begin{array}{l}\text { Vitamin D supple-mentation is } \\
\text { benefi-cial for the reduction of } \\
\text { hs-CRP inT2DM subjects but } \\
\text { does not have a signifi-cant } \\
\text { influence on TNF- } \alpha \text { and IL-6 } \\
\text { in T2DM subjects. }\end{array}$} \\
\hline & Farrokhian 2016 & 60 & Patients with type 2 diabetes mellitus & 25,000 IU/week Vitamin D3 & 26 weeks & & \\
\hline & Asemi 2016 & 66 & Patients with type 2 diabetes mellitus & 200 IU/day Vitamin D3 & 12 weeks & & \\
\hline & Tuomainen 2015 & 68 & Patients with type 2 diabetes mellitus & $1600-3200$ IU/day Vitamin D3 & 20 weeks & & \\
\hline & Sadiya 2015 & 82 & Patients with type 2 diabetes mellitus & 3000 - 6000 IU/day Vitamin D3 & 12 weeks & & \\
\hline & Gagnon 2014 & 80 & Patients with type 2 diabetes mellitus & 2000 IU/day Vitamin D3 & 26 weeks & & \\
\hline & Tabesh 2014 & 118 & Patients with type 2 diabetes mellitus & 50,000 IU/week Vitamin D3 & 8 weeks & & \\
\hline & Ghavamzadeh 2014 & 51 & Patients with type 2 diabetes mellitus & 400 IU/day Vitamin D3 & 14 weeks & & \\
\hline & Dalan 2016 & 64 & Patients with type 2 diabetes mellitus & 2000-4000 IU/day Vitamin D3 & 16 weeks & & \\
\hline & Jafari 2016 & 59 & Patients with type 2 diabetes mellitus & 2000 IU/day Vitamin D3 & 12 weeks & & \\
\hline & Al-Sofiani 2015 & 20 & Patients with type 2 diabetes mellitus & 5000 IU/day Vitamin D3 & 12 weeks & & \\
\hline & Akbarzadeh 2013 & 70 & Patients with type 2 diabetes mellitus & 20 IU/day Vitamin D3 & 12 weeks & & \\
\hline & Neyestani 2012 & 90 & Patients with type 2 diabetes mellitus & 500 IU/day Vitamin D3 & 12 weeks & & \\
\hline
\end{tabular}


Table 2. Cont.

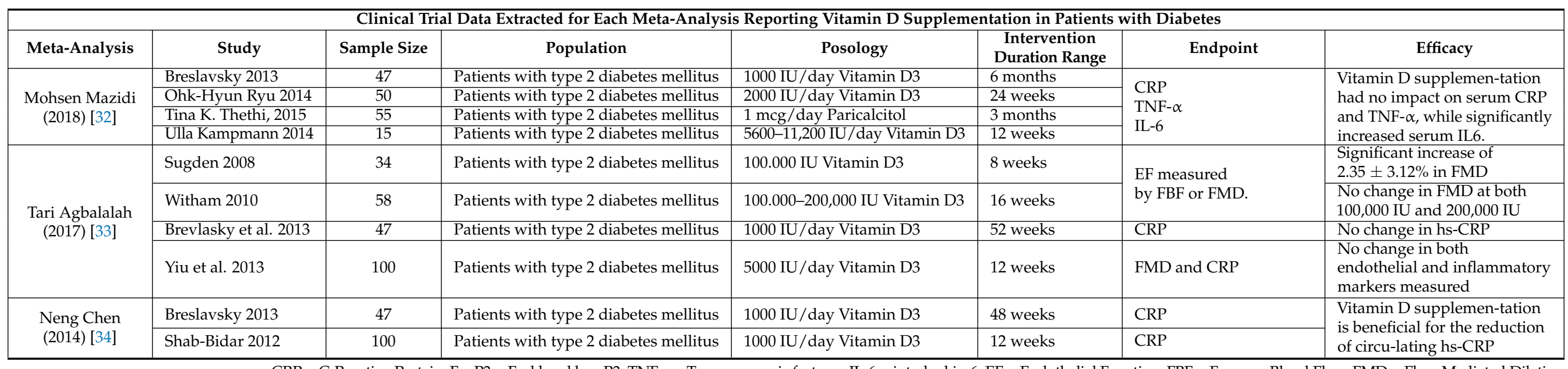

CRP = C-Reactive Protein, FoxP3 = Forkhead box P3, TNF- $\alpha=$ Tumor necrosis factor- $\alpha$ IL- 6 = interleukin-6, EF = Endothelial Function, FBF = Forearm Blood Flow, FMD = Flow Mediated Dilation. 


\section{Discussion}

SARS-CoV-2 is the novel coronavirus agent of the severe acute respiratory syndrome that brought about the COVID-19 pandemic [35]. The CoV genome encodes four main proteins: spike, membrane, nucleocapsid and envelope [36,37]. The virus' spike protein is responsible for the virus entry into host cells by recognizing and binding to a few receptors, such as ACE2, CD147 and sialic acid molecules. The viral spike protein that binds to the cell membrane receptors is proteolyzed by the transmembrane serine protease 2 , which facilitates its entry into target cells [38,39]. Once in the cell, the viral RNA genome is released into the cytoplasm to begin its replication process [40]. The virus can negatively regulate the expression of ACE2, leading to the upregulation of angiotensin II (Ang II). Ang II interacts with Ang II type 1 receptor (AT1R) to regulate nuclear factor-kb (NF-kB) signaling pathways, as well as the activation of macrophages, which leads to an overproduction of pro-inflammatory cytokines [41]. The key factor, in this positive feedback loop is IL-6, which causes cytokines to be released out of control [42]. IL-6 is an important functional marker of cellular senescence, and the age-dependent increase in IL-6 amplifier may correspond to the age-dependent increase in COVID-19 mortality [42,43]. More recent studies have also unveiled potential roles of ACE2 in regulating immune responses rather than simply being a viral linkage receptor in COVID-19 [42,44-48]. Once ligated to SARS-CoV-2, the expression of ACE2 on the host cell surface was significantly decreased. IL-6 in toll-like receptor signaling pathway could influence the immune system as a downstream effector [42,44-48]. Dysregulation of ACE2 induced by SARS-CoV-2 infection may further cause cytokine storms and pneumonia. Many more detailed pro-inflammatory and detrimental phenomena have been equally described, based on the interaction of SARS-CoV-2 and CD147 and sialic acid membrane receptors [20,49-53]. This increased cytokine production is usually defined as "cytokine storm". It also triggers a pathogenic inflammatory immune response, leading to severe multi-organ failure and death in patients with COVID-19 [54-56].

\subsection{Cytokine Storm}

Cytokine storm denomination has been used to describe hyperactive immune responses that can be initiated by a variety of factors, such as viral infections, autoimmune diseases and immunotherapies [57-59] Cytokine storms lead to the elimination of pathogenic microorganisms but also cause tissue toxicity affecting different organs [54,60]. Cytokine release syndrome (CRS), a type of systemic inflammation syndrome caused by cytokine storm, has been previously reported in patients infected with SARS-CoV and MERS-CoV. During viral infection, damage-associated molecular patterns (DAMPs) and pathogen-associated molecular patterns (PAMPs) can activate antiviral responses in nearby cells and recruit innate and adaptive immune cells, such as macrophages, natural killer (NK) cells and gamma delta (gd T) cells (Figure 1) [61-66]. Downstream production of interferons promotes intracellular antiviral defenses in neighboring epithelial cells. These may limit viral spread, whereas the release of IL-6 and IL-1b from other immune cells invokes the recruitment of neutrophils and T cells [62]. T-cell activation or immune cell lysis prompts the secretion of IFN-g and TNF-a, leading to the activation of immune cells and endothelial cells, with the further release of pro-inflammatory cytokines in a positive feedback loop [60]. These inflammatory mediators may promote thrombus formation [66]. This process, called immune-thrombosis, can also amplify cytokine production, and is illustrated by the binding of thrombin to inflammasome activation and IL-1 production [67]. Because vascular endothelial cells are exposed to circulating cytokines and other immune mediators, coagulation defects (such as capillary leak syndrome, thrombus formation and even DIC) may also be caused by endothelial cell dysfunction in cytokine storms, highlighting the crosstalk between hemostasis and cytokines $[61,66]$. The cytokine storm not only limits further spread of the virus but also induces secondary tissue damage through the secretion of massive amounts of active mediators and inflammatory factors [55-66,68-70]. 
The inhibition of this self-amplifying inflammatory cascade may not only control tissue damage but also impair viral clearance.

In COVID-19, Huang et al. had noted that patients in intensive care units (ICUs) had higher levels of plasma inflammatory cytokines IL-2, IL-7, IL-10, G-CSF (granulocyte colonystimulating factor), IFN- $\gamma$ and MCP, and TNF- $\alpha$ compared to patients not in ICUs [71]. These cytokines not only suggested the presence of Th1 answers but also the presence of Th2 answers in COVID-19. Furthermore, monocyte activation may imply that the cytokine storm in COVID-19 is closely correlated with disruption of the balance between innate and adaptive immunity. Recently, studies also showed that the level of IL-6 in severe cases was markedly higher than that in mild and moderate cases, but the levels of CD4+ T cells, CD8+ T cells and NK cells were decreased, indicating immunosuppression in severe COVID-19 patients [68]. Meanwhile, T lymphocyte cells were over-activated during cytokine storm in COVID-19 patients, which may be accompanied by severe immune dysfunction [72]. In a recent systematic review based on autopsy findings, in lung specimen and other organs, fibrin thrombi associated with increased CD61 positive platelets and megakaryocytes in pre-capillary and post-capillary vessels without complete luminal obstruction were observed in specimens collected from patients with COVID-19 [73]. Thus, a cytokine storm can directly damage the pulmonary capillary mucosa, promote alveolar oedema and further induce the spread of inflammatory cytokines, resulting in damage to alveolar structure and dysfunction in pulmonary ventilation [73,74]. In the same way, cytokine storm is also associated with the sequence and severity of organ dysfunction in multiple organ dysfunction syndrome (MODS) [69]. Hence, cytokine storm may be considered an important factor influencing the fate of patients with COVID-19 multi-organ disease.

\subsection{Innate and Adaptive Immune Response and COVID-19}

Innate and adaptive immune reactions cooperate with each other to produce immune protection [4]. Innate immune responses occur immediately after infection and are typically involved in virus removal, but it has a diminished antiviral capacity. Adaptive immunity is the key factor in the complete eradication of the virus [4]; this immune pathway needs 4 to 7 days to be activated after the occurrence of the infection. If an effective adaptive antiviral response is not generated in time to suppress the virus, innate immune responses will potentiate but are unable to effectively eradicate the virus, and this also leads to systemic inflammatory responses with the irrepressible release of inflammatory cytokines [75-78]. Elderly patients and those with chronic diseases need a longer period of time to generate adaptive and innate immune responses because of cell senescence. These patients rely only on the enhancement of antiviral innate immune responses in the early stages of infection, generating a higher risk of cytokine storms; thus a more rapid evolution towards severe disease is expected. It is still unclear whether the immune hyperactivity is due to ongoing viral replication or immune dysregulation [66]. Lastly, the NLR family pyrin domain containing 3 (NLRP3) is the most acknowledged inflammasome pattern which takes place in COVID-19, including most of the immune-inflammatory pathways elucidated above.

Interestingly, diabetic patients show an upregulated NRLP3 pathway [79] which could be one of the possible explanations of their susceptibility to this viral infection. At the same time, it was shown that, among the possible compounds that specifically target the NRLP3 inflammasome, vitamin D proved to downregulate this pathway, inhibiting IL- $1 \beta$ secretion in macrophages in vivo [80].

Taken together, viral escape to avoid antiviral immunity, may compromise viral clearance, resulting in inappropriate immune activation and, consequently, causing cytokine storms [81]. Thereby, this activation of innate immunity may be an important factor in the development of cytokine storms in COVID-19 [82].

\subsection{Vitamin D}

Vitamin D, a secosteroid hormone, regulates calcium and phosphate homeostasis but also cell proliferation and differentiation. It plays a vital role in keeping the mineral- 
ized skeleton healthy, and it also plays a crucial function in the response of the immune system $[83,84]$. Experimental and animal studies have shown, firstly, that vitamin D has important biological activities on the innate and adaptive immune system and, secondly, that the administration of vitamin D changes the onset and progression of various immunefactor diseases [85]. Humans get their vitamin D from sunlight, diet and supplements. The two main forms are: vitamin D2 or ergocalciferol and vitamin D3 or cholecalciferol. After entering the circulation, vitamin D (D expresses both vitamin D2 and D3) is metabolized by vitamin D-25-hydroxylase (CYP2R1) in the liver to 25-hydroxyvitamin D or calcifediol [25 $(\mathrm{OH}) \mathrm{D}] .25(\mathrm{OH}) \mathrm{D}$ is further metabolized, mainly in the kidneys, by the enzyme 25-hydroxyvitamin D-1 $\alpha$-hydroxylase (CYP27B1) into the active form, 1,25-dihydroxyvitamin or calcitriol $(\mathrm{CT})[1,25(\mathrm{OH}) 2 \mathrm{D}][84,86]$. Then, 1,25 (OH)2 D employs its physiological functions by binding to the vitamin $\mathrm{D}$ receptor (VDR) in the cytoplasm of cells, stimulating the heterodimerization of the VDR with the retinoid $X$ receptor (RXR), forming a VDR-RXR-hormone complex [15]; in the nucleus, it leads to the up- or downregulation of a multitude of genes [84]. Kidneys are the primary site of the conversion of $25(\mathrm{OH})$ D to systemically bioavailable 1,25 (OH)2 D. CYP27B1 is also expressed by many other tissues, including activated macrophages, parathyroid glands, microglia, breast, colon and keratinocytes, wherein 1,25 $(\mathrm{OH}) 2 \mathrm{D}$ is produced and exercises its autocrine and paracrine function $[83,85,87]$.

During an infection, macrophages and monocytes are recruited to the inflammatory site; the exposure to inflammatory cytokines expresses CYP27B1, which converts $25(\mathrm{OH}) \mathrm{D}$ to $1,25(\mathrm{OH}) 2 \mathrm{D}$ [88]. Then, 1,25 $(\mathrm{OH}) 2 \mathrm{D}$ develops the antimicrobial activities of macrophages and monocytes. Furthermore, 1,25 $(\mathrm{OH}) 2 \mathrm{D}$ suppresses the expression of toll-like receptors on monocytes and inhibits the production of some inflammatory cytokines such as IL-2, IL-6 and IL-17 [85,89,90]. Experimental studies have also shown that natural killer (NK) cell differentiation and function can be modulated by 1,25 $(\mathrm{OH}) 2 \mathrm{D}$ administration. At present, the data regarding the influence of 1,25 $(\mathrm{OH}) 2 \mathrm{D}$ on NK cells are still inconsistent [91-93].

Through multiple genomic and extragenomic pathways, numerous experimental studies have demonstrated that vitamin D and its metabolites modulate endothelial function and vascular permeability [94]. Other studies have indicated that 1,25 (OH)2 D3 is a transcriptional regulator of endothelial nitric oxide synthase (eNOS). This causes the upregulation of eNOS gene expression and consequently, an increase in endothelial nitric oxide production $[93,95,96]$. In local and systemic inflammation, vitamin D and its metabolites employ pleiotropic effects on vascular endothelium that are protective against vascular dysfunction and tissue damage $[97,98]$. Vitamin D may also activate hepcidinantagonist pathways, regulating the hepcidin-ferroportin axis, which can be of help in COVID-19, for which hyperferritinemia is one of the major negative prognostic factors [20]. Vitamin D3 may also have an anticoagulant effect, in contrast to cholecalciferol insufficiency, which may be pro-thrombotic [99]. Recent studies showed that, in intensive care patients, 100,000 IU/day of cholecalciferol for five days resulted in higher and lower levels of hemoglobin and hepcidin, respectively. Cholecalciferol showed upregulatory epigenetic action on a few antioxidant systems too [100].

It was observed that a drastic shift from the proinflammatory state to a more regulated immune-inflammatory activity is achieved as a result of the local production of $1,25(\mathrm{OH}) 2 \mathrm{D}$ by monocytes/macrophages [101]. This is considered one of the reasons why vitamin $D$ might exert protective effects against autoimmune diseases. Other studies have also demonstrated that a decreased CD4/CD8 ratio was associated with low 25(OH)D levels [102] and that the administration of 5000-10,000 IU of vitamin D3 was attributable to an increase in the CD4/CD8 ratio, reflecting immune regulation [103,104].

As regards B lymphocytes, inactive B lymphocytes do not have VDRs but only upregulate their VDR expression when they are activated to proliferate with mitogens [105]. Furthermore, 1,25(OH)2D inhibits immunoglobulin synthesis and therefore could potentially interfere with the immune system, and 1,25(OH)2D also regulates B-cell activity. 
The hyperactive state of $1,25(\mathrm{OH}) 2 \mathrm{D}$ appears to attenuate the immunoglobulin immune response through a variety of mechanisms [105-109].

By controlling B cell activity and the transformation of B cells into plasma cells, $1,25(\mathrm{OH}) 2 \mathrm{D}$ contributes to a reduction in autoantibody production, resulting in a reduced risk of antibody-mediated autoimmune disorders $[99,104,105,110]$.

\subsection{The Link among Diabetes, Vitamin D and COVID-19 Pandemic}

It is well-known that people with diabetes are at higher risk of infections [111,112]. Diabetes is characterized by a hyperglycemic environment that promotes immune dysfunction through a variety of ways. In particular, in patients with DM, monocytes and mononuclear cells secrete less interleukin 1 (IL-1) and IL-6 when stimulated by lipopolysaccharide $[113,114]$. The low production of interleukins seems to be the result of inherent defects $[113,115]$. Hyperglycemia is also characterized by the reduced mobilization, chemotaxis and phagocytic activity of polymorphonuclear leukocytes [114,116,117]. A hyperglycemic environment blocks antibacterial function by inhibiting glucose 6-phosphate dehydrogenase (G6PD), increases the apoptosis of polymorphonuclear leukocytes and reduces the migration of polymorphonuclear leukocytes through the endothelium [114]. A reduction in $\mathrm{C} 4$ is associated with polymorphonuclear dysfunction and reduced cytokine production [111,113]. In addition, a hyperglycemic environment will increase intracellular glucose levels and then the utilization of NADPH as a cofactor for metabolism. The reduction of NADPH levels prevents the regeneration of molecules that play a key role in the cellular antioxidant mechanism, thus increasing sensitivity to oxidative stress. When glycosylated hemoglobin $(\mathrm{HbA} 1 \mathrm{c})$ is more than $8.0 \%$, the proliferation function of CD4 $\mathrm{T}$ lymphocytes and their response to antigens by the altered expression of cellular adhesion molecules are affected [114]. Moreover, the virulence of different pathogens can be increased by hyperglycemia $[116,117]$.

Concerning SARS-CoV-2 infection, clinical reports found DM to be one of the mostcommon comorbidities present in patients exhibiting a more severe course of the disease [118]. Generally, the susceptibility to the viral action seems to depend mainly on the typology/expression of the host cell receptors and on the affinity of the spike with these receptors. Interestingly, diabetic (and obese) patients show an overexpression of CD147 receptors [20], of ACE2 molecules [119] and, especially, the altered glycosylation of all membrane receptors [120,121]. Lastly, hepcidin axis upregulation has been detected in diabetic patients [122], which reinforces the likelihood of intracellular ferritin overconcentration in these individuals.

Overall, this altered profile of cell membrane receptors in DM may be one of the main factors explaining the higher susceptibility of these patients to COVID-19.

A link between hyperglycemia and ACE2r levels and the severity of COVID-19 disease has been documented, probably due to the changes in ACE2r glycosylation and viral spike protein glycosylation. Both may be caused by uncontrolled hyperglycemia, which may modify the binding of the viral spike protein to ACE2r and the degree of immune response to the virus [123].

Elevated blood glucose levels can directly increase the glucose concentration in airway secretions [124]. In uncontrolled hyperglycemia, high and abnormally glycosylated cell receptors in the lungs, nasal airways, tongue and oropharynx may also serve as increased SARS-CoV-2 virus binding sites, resulting in a higher trend of COVID-19 infection and more serious forms of the disease [123]. Glycemic control could reduce the levels of glycosylated ACE2r target in the lung, decreasing the number of glycosylated viral binding sites and possibly ameliorating inflammation and the symptoms of COVID-19 disease [123]. Hyperglycemia may also affect pulmonary function, and this effect could be linked to ACE2r overexpression in the lungs of diabetics [19].

In patients with diabetes, higher circulating glucose levels will result in a higher percentage of glycated hemoglobin. SARS-CoV-2 surface proteins seem to bind to and potentially impair the heme molecule within red blood cells. In this way, a separation of 
iron from the molecule to form porphyrin occurs, determining in red blood cells an altered oxygen and carbon dioxide carriage, with consequent possible systemic alterations induced by free heme circulation $[20,125]$.

Whereas diabetics and older subjects have more glycated hemoglobin, they may be preferentially affected by SARS-CoV-2 binding and dissociation of iron from heme to form porphyrins, and another receptor (CD147 or basigin) might be involved [49]. Affecting overall hemoglobin functionality, DM may alter oxygen transportation capacity, which may significantly impact the hypoxia patterns of these patients. Different studies reported that diabetic patients have low $25(\mathrm{OH}) \mathrm{D}$ levels, which may be due to impaired liver and kidney metabolism of vitamin $\mathrm{D}$, reduced dietary vitamin $\mathrm{D}$ intake and decreased intestinal absorption of vitamin D caused by diabetic autonomic neuropathy [126-128]. In addition, it has been reported that low circulating $25(\mathrm{OH}) \mathrm{D}$ levels are associated with poor blood glucose control in diabetic patients. Prospective studies have shown that vitamin D deficiency may increase the risk of fasting blood glucose impaired and diabetes [129-131]. Furthermore, a clear association between hypovitaminosis D, obesity and diabetes mellitus, factors known to increase COVID-19 severity risks, have been widely recognized [126,127,132,133].

It worth to outline that vitamin $\mathrm{D}$ deficiency has been hypothesized to predispose individuals to SARS-CoV-2 infection and to increase COVID-19 severity. According to Di Filippo et al. [132], patients suffering from vitamin D deficiency and hyperglycemia were at a higher risk of severe COVID-19, higher inflammatory response and worse disease outcomes.

It was estimated that about 1 billion people worldwide have low vitamin $\mathrm{D}$ levels, and this is detected in all ethnicities and age groups [134]. Moreover, a significantly higher prevalence of vitamin D deficiency is reported in DM2 (83.5\%) compared to normoglycemic controls in a north Indian community [126]. Tecilazich and colleagues found low 25(OH)D levels in diabetic patients with retinopathy [134], suggesting that hypovitaminosis D may worsen the predisposition of patients with diabetes to the microvascular damage typical of COVID-19. It was shown that supplementation with vitamin D may improve glucose metabolism control by reducing insulin resistance and stimulating $\beta$-cell function $[135,136]$, especially in patients with poor baseline blood glucose control [137].

A recent cross-sectional study showed that there is a statistically negative correlation between 25(OH)D levels and the homeostasis model assessment of insulin resistance, but this association was only found in the female population and not in men [138]. Moreover, some studies have suggested that vitamin $\mathrm{D}$ treatment may slow the progression to diabetes in patients either at high risk of diabetes or with prediabetes, specifically in those with low baseline $25(\mathrm{OH}) \mathrm{D}$ levels [139].

Low $25(\mathrm{OH}) \mathrm{D}$ levels may be a predisposing factor in the bidirectional interrelation between diabetes and COVID-19, increasing from one side the susceptibility of diabetics to the infection, from the other side promoting the diabetogenic effect of COVID-19 in terms of endothelial dysfunction and microvascular complications.

Obesity and overweight may equally play a role in COVID-19. High BMI and altered body composition, with increased adiposity, are reported as independent risk factors for greater disease severity and poor prognosis in COVID-19 patients [139,140]. Interestingly, low levels of $25(\mathrm{OH}) \mathrm{D}$ were frequently reported in obese and overweight patients, being inversely related to BMI and adiposity [132,141], negatively influencing skeletal and muscle health, with a resulting increased predisposition to an obese osteosarcopenic phenotype [142,143]. In fact, BMI has also been reported to predict resistance to vitamin D [144]. A possible direct relationship between vitamin D status, adiposity, age and COVID-19 severity has been previously hypothesized. In fact, aging and fat accumulation may decrease vitamin D bioavailability and efficacy [29]. A low vitamin D status is present in obese patients and patients with metabolic syndrome, and these conditions are associated with reduced hepatic 25-hydroxylation of vitamin D. Experimental studies showed that CYP2R1 (the major vitamin D-25 hydroxylase) is lower in the livers of obese mice in comparison with normal mice [145]. According to Ekwaru and colleagues obese and overweight subjects had serum $25(\mathrm{OH}) \mathrm{D}$ significantly lower than normal weight people 
and vitamin D supplementation would be 2 to 3 times higher and 1.5 times higher for obese and overweight subjects respectively, in comparison with normal weight subjects [146].

A recent study showed that a strong relationship exists among vitamin D, glycemia and BMI in COVID-19 subjects [147]. Vitamin D deficiency could be identified as a common pathophysiological mechanism involved in the detrimental effect of hyperglycemia and adiposity on disease severity.

Overall, a clear-cut effect of vitamin D serum level on COVID-19 incidence and prognosis was demonstrated [30], which may be explained through the several beneficial effects of this pre-hormone on several biochemical pathways that may putatively contrast the viral invasiveness.

This umbrella review demonstrated that vitamin D supplementation in subjects with diabetes leads to improved circulating inflammatory biomarkers, representing an adjuvant therapy for COVID-19 patients with diabetes and a vitamin D status deficiency. It can therefore be affirmed that, based upon this umbrella review, a strong rationale exists for the therapeutic administration of supplemental vitamin D in order to reduce COVID-19 respiratory complications or prevent, in case of infection, a severe form of COVID-19.

The major strength of this analysis is represented by the resolution of the clinical heterogeneity problem. The presence of clinical heterogeneity across studies is related to the different characteristics and health conditions of the participants included. In this sense, we considered only patients affected by diabetes and according to the different types of diabetes. In addition, our analysis also highlights the heterogeneity of treatments [29-34]. In fact, heterogeneity exists in doses of the vitamin administerd to the target population. This study has a limitation. The umbrella review makes a qualitative assessment and compiles all the evidence from existing reviews on a topic through to a specified date. Through extensive searching, an additional thirteen randomized clinical trials [RCTs] are available at this time and, obviously, had not been considered in this umbrella review. For this reason, further studies are necessary for the evaluation of these RCTs. In this sense, it must be outlined that, according to Sabico et al. [148], oral supplementation with vitamin D3 reduces the time to recovery for cough and ageusia among patients with COVID-19, highlighting the beneficial effects of vitamin D supplementation against COVID-19. On the contrary, it is worth it to outline that recent studies showed that longterm supplementation with vitamin $\mathrm{D}(3)$ did not reduce IL-6, hsCRP or NT-proBNP in patients with type 2 diabetes [149]; additionally, high-dose vitamin D supplementation did not improve biomarkers of glycemia, inflammation, neurohormonal activation or lipids [150].

\section{Conclusions}

Our overview of systematic reviews concerning vitamin D's role in the inflammatory processes, highlighted a series of documented interactions among this molecule and a large series of cell metabolic pathways involved in DM and the potential application in patients with diabetes and COVID-19. Current evidence supports the benefits of vitamin D supplementation for managing or treating both of these pathological conditions. Most of the literature reports showed that vitamin D supplementation significantly reduce CRP in diabetic patients, while contrasting data are available about IL-6. Further studies should highlight the optimal treatment doses for the maximum benefit to patients. Meanwhile, vitamin D deficiency should be corrected, since vitamin D supplementation is safe, and it results in potential benefits on the cytokine storm by reducing the severity of several respiratory complications of COVID-19.

Author Contributions: Conceptualization, S.C. and C.A.; methodology, S.C., G.N. and C.A.; software, G.N.; validation, S.C. and C.A.; formal analysis, R.M.B. and M.L.M.; investigation, R.M.B., M.L.M. and C.A.; resources, R.M.B. and M.L.M.; data curation, G.N., R.M.B., M.L.M. and S.S.; writing-original draft preparation, C.A.; writing-review and editing, C.A., S.C., A.C. and E.T.; visualization, G.N.; supervision, S.C.; project administration, C.A. All authors have read and agreed to the published version of the manuscript. 
Funding: This research received no external funding.

Institutional Review Board Statement: Not applicable.

Informed Consent Statement: Not applicable.

Data Availability Statement: Not applicable.

Conflicts of Interest: The authors declare no conflict of interest.

\section{References}

1. Zhu, N.; Zhang, D.; Wang, W.; Li, X.; Yang, B.; Song, J.; Zhao, X.; Huang, B.; Shi, W.; Lu, R.; et al. A Novel Coronavirus from Patients with Pneumonia in China, 2019. N. Engl. J. Med. 2020, 382, 727-733. [CrossRef] [PubMed]

2. WHO Director-General's Opening Remarks at the Media Briefing on COVID-19-11 March 2020. Available online: https:/ / www.who.int/director-general/speeches/detail/who-director-general-s-opening-remarks-at-the-media-briefing-oncovid-19---11-march-2020 (accessed on 1 February 2022).

3. COVID-19 Map. Available online: https://coronavirus.jhu.edu/map.html (accessed on 1 February 2022).

4. Wang, D.; Hu, B.; Hu, C.; Zhu, F.; Liu, X.; Zhang, J.; Wang, B.; Xiang, H.; Cheng, Z.; Xiong, Y.; et al. Clinical Characteristics of 138 Hospitalized Patients with 2019 Novel Coronavirus-Infected Pneumonia in Wuhan, China. JAMA 2020, 323, 1061-1069. [CrossRef] [PubMed]

5. Lenti, M.V.; Corazza, G.R.; Di Sabatino, A. Carving out a Place for Internal Medicine during COVID-19 Epidemic in Italy. J. Intern. Med. 2020, 288, 263-265. [CrossRef]

6. Corrao, S.; Pinelli, K.; Vacca, M.; Raspanti, M.; Argano, C. Type 2 Diabetes Mellitus and COVID-19: A Narrative Review. Front. Endocrinol. 2021, 12, 609470. [CrossRef] [PubMed]

7. Hypertension and COVID-19. Available online: https://www.who.int/publications-detail-redirect/WHO-2019-nCoV-Sci_BriefHypertension-2021.1 (accessed on 1 February 2022).

8. Bansal, M. Cardiovascular Disease and COVID-19. Diabetes Metab. Syndr. 2020, 14, 247-250. [CrossRef]

9. Gibertoni, D.; Reno, C.; Rucci, P.; Fantini, M.P.; Buscaroli, A.; Mosconi, G.; Rigotti, A.; Giudicissi, A.; Mambelli, E.; Righini, M.; et al. COVID-19 Incidence and Mortality in Non-Dialysis Chronic Kidney Disease Patients. PLoS ONE 2021, 16, e0254525. [CrossRef] [PubMed]

10. Gerayeli, F.V.; Milne, S.; Cheung, C.; Li, X.; Yang, C.W.T.; Tam, A.; Choi, L.H.; Bae, A.; Sin, D.D. COPD and the Risk of Poor Outcomes in COVID-19: A Systematic Review and Meta-Analysis. EClinicalMedicine 2021, 33, 100789. [CrossRef]

11. International Diabetes Federation. IDF Diabetes Atlas, 9th ed.; International Diabetes Federation: Brussels, Belgium, 2019. Available online: https://diabetesatlas.org/idfawp/resource-files/2019/07/IDF_diabetes_atlas_ninth_edition_en.pdf (accessed on 25 October 2021).

12. Guan, W.-J.; Liang, W.-H.; Zhao, Y.; Liang, H.-R.; Chen, Z.-S.; Li, Y.-M.; Liu, X.-Q.; Chen, R.-C.; Tang, C.-L.; Wang, T.; et al. Comorbidity and Its Impact on 1590 Patients with COVID-19 in China: A Nationwide Analysis. Eur. Respir. J. 2020, $55,2000547$. [CrossRef]

13. Gupta, R.; Hussain, A.; Misra, A. Diabetes and COVID-19: Evidence, Current Status and Unanswered Research Questions. Eur. J. Clin. Nutr. 2020, 74, 864-870. [CrossRef]

14. Hill, M.A.; Mantzoros, C.; Sowers, J.R. Commentary: COVID-19 in Patients with Diabetes. Metabolism 2020, $107,154217$. [CrossRef]

15. Dennis, J.M.; Mateen, B.A.; Sonabend, R.; Thomas, N.J.; Patel, K.A.; Hattersley, A.T.; Denaxas, S.; McGovern, A.P.; Vollmer, S.J. Type 2 Diabetes and COVID-19-Related Mortality in the Critical Care Setting: A National Cohort Study in England, March-July 2020. Diabetes Care 2021, 44, 50-57. [CrossRef] [PubMed]

16. Hussain, A.; Bhowmik, B.; do Vale Moreira, N.C. COVID-19 and Diabetes: Knowledge in Progress. Diabetes Res. Clin. Pract. 2020, 162, 108142. [CrossRef] [PubMed]

17. Muniyappa, R.; Gubbi, S. COVID-19 Pandemic, Coronaviruses, and Diabetes Mellitus. Am. J. Physiol. Endocrinol. Metab. 2020, 318, E736-E741. [CrossRef] [PubMed]

18. Mehta, P.; McAuley, D.F.; Brown, M.; Sanchez, E.; Tattersall, R.S.; Manson, J.J.; Haemophagocytic Lymphohistiocytosis Across Speciality Collaboration. COVID-19: Consider Cytokine Storm Syndromes and Immunosuppression. Lancet 2020, 395, 1033-1034. [CrossRef]

19. Rao, S.; Lau, A.; So, H.-C. Exploring Diseases/Traits and Blood Proteins Causally Related to Expression of ACE2, the Putative Receptor of SARS-CoV-2: A Mendelian Randomization Analysis Highlights Tentative Relevance of Diabetes-Related Traits. Diabetes Care 2020, 43, 1416-1426. [CrossRef]

20. Cavezzi, A.; Troiani, E.; Corrao, S. COVID-19: Hemoglobin, Iron, and Hypoxia beyond Inflammation. A Narrative Review. Clin. Pract. 2020, 10, 1271. [CrossRef]

21. Bornstein, S.R.; Dalan, R.; Hopkins, D.; Mingrone, G.; Boehm, B.O. Endocrine and Metabolic Link to Coronavirus Infection. Nat. Rev. Endocrinol. 2020, 16, 297-298. [CrossRef]

22. Mutt, S.J.; Hyppönen, E.; Saarnio, J.; Järvelin, M.-R.; Herzig, K.-H. Vitamin D and Adipose Tissue-More than Storage. Front. Physiol. 2014, 5, 228. [CrossRef] 
23. Dong, J.-Y.; Zhang, W.-G.; Chen, J.J.; Zhang, Z.-L.; Han, S.-F.; Qin, L.-Q. Vitamin D Intake and Risk of Type 1 Diabetes: A Meta-Analysis of Observational Studies. Nutrients 2013, 5, 3551-3562. [CrossRef]

24. Littorin, B.; Blom, P.; Schölin, A.; Arnqvist, H.J.; Blohmé, G.; Bolinder, J.; Ekbom-Schnell, A.; Eriksson, J.W.; Gudbjörnsdottir, S.; Nyström, L.; et al. Lower Levels of Plasma 25-Hydroxyvitamin D among Young Adults at Diagnosis of Autoimmune Type 1 Diabetes Compared with Control Subjects: Results from the Nationwide Diabetes Incidence Study in Sweden (DISS). Diabetologia 2006, 49, 2847-2852. [CrossRef]

25. Afzal, S.; Bojesen, S.E.; Nordestgaard, B.G. Low 25-Hydroxyvitamin D and Risk of Type 2 Diabetes: A Prospective Cohort Study and Metaanalysis. Clin. Chem. 2013, 59, 381-391. [CrossRef] [PubMed]

26. Song, Y.; Wang, L.; Pittas, A.G.; Del Gobbo, L.C.; Zhang, C.; Manson, J.E.; Hu, F.B. Blood 25-Hydroxy Vitamin D Levels and Incident Type 2 Diabetes: A Meta-Analysis of Prospective Studies. Diabetes Care 2013, 36, 1422-1428. [CrossRef] [PubMed]

27. Wu, C.; Chen, X.; Cai, Y.; Xia, J.; Zhou, X.; Xu, S.; Huang, H.; Zhang, L.; Zhou, X.; Du, C.; et al. Risk Factors Associated with Acute Respiratory Distress Syndrome and Death in Patients with Coronavirus Disease 2019 Pneumonia in Wuhan, China. JAMA Intern. Med. 2020, 180, 934-943. [CrossRef] [PubMed]

28. Herold, T.; Jurinovic, V.; Arnreich, C.; Lipworth, B.J.; Hellmuth, J.C.; von Bergwelt-Baildon, M.; Klein, M.; Weinberger, T. Elevated Levels of IL-6 and CRP Predict the Need for Mechanical Ventilation in COVID-19. J. Allergy Clin. Immunol. 2020, 146, 128-136.e4. [CrossRef] [PubMed]

29. Asbaghi, O.; Sadeghian, M.; Mozaffari-Khosravi, H.; Maleki, V.; Shokri, A.; Hajizadeh-Sharafabad, F.; Alizadeh, M.; Sadeghi, O. The Effect of Vitamin D-Calcium Co-Supplementation on Inflammatory Biomarkers: A Systematic Review and Meta-Analysis of Randomized Controlled Trials. Cytokine 2020, 129, 155050. [CrossRef]

30. Fisher, S.A.; Rahimzadeh, M.; Brierley, C.; Gration, B.; Doree, C.; Kimber, C.E.; Cajide, A.P.; Lamikanra, A.A.; Roberts, D.J. The Role of Vitamin D in Increasing Circulating T Regulatory Cell Numbers and Modulating T Regulatory Cell Phenotypes in Patients with Inflammatory Disease or in Healthy Volunteers: A Systematic Review. PLoS ONE 2019, 14, e0222313. [CrossRef]

31. Yu, Y.; Tian, L.; Xiao, Y.; Huang, G.; Zhang, M. Effect of Vitamin D Supplementation on Some Inflammatory Biomarkers in Type 2 Diabetes Mellitus Subjects: A Systematic Review and Meta-Analysis of Randomized Controlled Trials. Ann. Nutr. Metab. 2018, 73, 62-73. [CrossRef]

32. Mazidi, M.; Rezaie, P.; Vatanparast, H. Impact of vitamin D supplementation on C-reactive protein; a systematic review and meta-analysis of randomized controlled trials. BMC Nutr. 2018, 4, 1. [CrossRef]

33. Agbalalah, T.; Hughes, S.F.; Freeborn, E.J.; Mushtaq, S. Impact of vitamin D supplementation on endothelial and inflammatory markers in adults: A systematic review. J. Steroid Biochem. Mol. Biol. 2017, 173, 292-300. [CrossRef]

34. Chen, N.; Wan, Z.; Han, S.F.; Li, B.Y.; Zhang, Z.L.; Qin, L.Q. Effect of vitamin D supplementation on the level of circulating high-sensitivity C-reactive protein: A meta-analysis of randomized controlled trials. Nutrients 2014, 6, 2206-2216. [CrossRef]

35. Corman, V.M.; Muth, D.; Niemeyer, D.; Drosten, C. Hosts and Sources of Endemic Human Coronaviruses. Adv. Virus Res. 2018, 100, 163-188. [CrossRef] [PubMed]

36. da Costa, V.G.; Moreli, M.L.; Saivish, M.V. The Emergence of SARS, MERS and Novel SARS-2 Coronaviruses in the 21st Century. Arch. Virol. 2020, 165, 1517-1526. [CrossRef] [PubMed]

37. Petrosillo, N.; Viceconte, G.; Ergonul, O.; Ippolito, G.; Petersen, E. COVID-19, SARS and MERS: Are They Closely Related? Clin. Microbiol. Infect. 2020, 26, 729-734. [CrossRef] [PubMed]

38. Hoffmann, M.; Kleine-Weber, H.; Schroeder, S.; Krüger, N.; Herrler, T.; Erichsen, S.; Schiergens, T.S.; Herrler, G.; Wu, N.-H.; Nitsche, A.; et al. SARS-CoV-2 Cell Entry Depends on ACE2 and TMPRSS2 and Is Blocked by a Clinically Proven Protease Inhibitor. Cell 2020, 181, 271-280.e8. [CrossRef]

39. Rabi, F.A.; Al Zoubi, M.S.; Kasasbeh, G.A.; Salameh, D.M.; Al-Nasser, A.D. SARS-CoV-2 and Coronavirus Disease 2019: What We Know So Far. Pathogens 2020, 9, 231. [CrossRef]

40. Yuki, K.; Fujiogi, M.; Koutsogiannaki, S. COVID-19 Pathophysiology: A Review. Clin. Immunol. 2020, 215, 108427. [CrossRef]

41. Banu, N.; Panikar, S.S.; Leal, L.R.; Leal, A.R. Protective Role of ACE2 and Its Downregulation in SARS-CoV-2 Infection Leading to Macrophage Activation Syndrome: Therapeutic Implications. Life Sci. 2020, 256, 117905. [CrossRef]

42. Jiang, F.; Yang, J.; Zhang, Y.; Dong, M.; Wang, S.; Zhang, Q.; Liu, F.F.; Zhang, K.; Zhang, C. Angiotensin-Converting Enzyme 2 and Angiotensin 1-7: Novel Therapeutic Targets. Nat. Rev. Cardiol. 2014, 11, 413-426. [CrossRef]

43. Zaki, A.M.; van Boheemen, S.; Bestebroer, T.M.; Osterhaus, A.D.M.E.; Fouchier, R.A.M. Isolation of a Novel Coronavirus from a Man with Pneumonia in Saudi Arabia. N. Engl. J. Med. 2012, 367, 1814-1820. [CrossRef]

44. Liu, F.; Long, X.; Zou, W.; Fang, M.; Wu, W.; Li, W.; Zhang, B.; Zhang, W.; Chen, X.; Zhang, Z. Highly ACE2 Expression in Pancreas May Cause Pancreas Damage After SARS-CoV-2 Infection; Infectious Diseases (except HIV/AIDS). medRxiv 2020. [CrossRef]

45. Šestan, M.; Marinović, S.; Kavazović, I.; Cekinović, Đ.; Wueest, S.; Wensveen, T.T.; Brizić, I.; Jonjić, S.; Konrad, D.; Wensveen, F.M.; et al. Virus-Induced Interferon- $\gamma$ Causes Insulin Resistance in Skeletal Muscle and Derails Glycemic Control in Obesity. Immunity 2018, 49, 164-177.e6. [CrossRef] [PubMed]

46. Yang, J.-K.; Lin, S.-S.; Ji, X.-J.; Guo, L.-M. Binding of SARS Coronavirus to Its Receptor Damages Islets and Causes Acute Diabetes. Acta Diabetol. 2010, 47, 193-199. [CrossRef] [PubMed]

47. Philips, B.J.; Meguer, J.-X.; Redman, J.; Baker, E.H. Factors Determining the Appearance of Glucose in Upper and Lower Respiratory Tract Secretions. Intensive Care Med. 2003, 29, 2204-2210. [CrossRef] [PubMed] 
48. Zamorano Cuervo, N.; Grandvaux, N. ACE2: Evidence of role as entry receptor for SARS-CoV-2 and implications in comorbidities. Elife 2020, 9, e61390. [CrossRef]

49. Radzikowska, U.; Ding, M.; Tan, G.; Zhakparov, D.; Peng, Y.; Wawrzyniak, P.; Wang, M.; Li, S.; Morita, H.; Altunbulakli, C.; et al. Distribution of ACE2, CD147, CD26, and Other SARS-CoV-2 Associated Molecules in Tissues and Immune Cells in Health and in Asthma, COPD, Obesity, Hypertension, and COVID-19 Risk Factors. Allergy 2020, 75, 2829-2845. [CrossRef]

50. Wang, K.; Chen, W.; Zhang, Z.; Deng, Y.; Lian, J.-Q.; Du, P.; Wei, D.; Zhang, Y.; Sun, X.-X.; Gong, L.; et al. CD147-Spike Protein Is a Novel Route for SARS-CoV-2 Infection to Host Cells. Signal Transduct. Target Ther. 2020, 5, 283. [CrossRef]

51. Wielgat, P.; Rogowski, K.; Godlewska, K.; Car, H. Coronaviruses: Is Sialic Acid a Gate to the Eye of Cytokine Storm? From the Entry to the Effects. Cells 2020, 9, 1963. [CrossRef]

52. Robson, B. Bioinformatics Studies on a Function of the SARS-CoV-2 Spike Glycoprotein as the Binding of Host Sialic Acid Glycans. Comput. Biol. Med. 2020, 122, 103849. [CrossRef]

53. Sun, X.-L. The Role of Cell Surface Sialic Acids for SARS-CoV-2 Infection. Glycobiology 2021, 31, 1245-1253. [CrossRef]

54. Zaim, S.; Chong, J.H.; Sankaranarayanan, V.; Harky, A. COVID-19 and Multiorgan Response. Curr. Probl. Cardiol. 2020, 45, 100618. [CrossRef]

55. Li, X.; Geng, M.; Peng, Y.; Meng, L.; Lu, S. Molecular Immune Pathogenesis and Diagnosis of COVID-19. J. Pharm. Anal. 2020, 10, 102-108. [CrossRef] [PubMed]

56. Nile, S.H.; Nile, A.; Qiu, J.; Li, L.; Jia, X.; Kai, G. COVID-19: Pathogenesis, Cytokine Storm and Therapeutic Potential of Interferons. Cytokine Growth Factor Rev. 2020, 53, 66-70. [CrossRef] [PubMed]

57. Shimabukuro-Vornhagen, A.; Gödel, P.; Subklewe, M.; Stemmler, H.J.; Schlößer, H.A.; Schlaak, M.; Kochanek, M.; Böll, B.; von Bergwelt-Baildon, M.S. Cytokine Release Syndrome. J. Immunother. Cancer 2018, 6, 56. [CrossRef] [PubMed]

58. Ferrara, J.L.; Abhyankar, S.; Gilliland, D.G. Cytokine Storm of Graft-Versus-Host Disease: A Critical Effector Role for Interleukin-1. Transpl. Proc. 1993, 25, 1216-1217.

59. Lee, D.W.; Gardner, R.; Porter, D.L.; Louis, C.U.; Ahmed, N.; Jensen, M.; Grupp, S.A.; Mackall, C.L. Current Concepts in the Diagnosis and Management of Cytokine Release Syndrome. Blood 2014, 124, 188-195. [CrossRef]

60. Klinkhammer, J.; Schnepf, D.; Ye, L.; Schwaderlapp, M.; Gad, H.H.; Hartmann, R.; Garcin, D.; Mahlakõiv, T.; Staeheli, P. IFN- $\lambda$ Prevents Influenza Virus Spread from the Upper Airways to the Lungs and Limits Virus Transmission. eLife 2018, 7, e33354. [CrossRef]

61. Kawai, T.; Akira, S. Innate Immune Recognition of Viral Infection. Nat. Immunol. 2006, 7, 131-137. [CrossRef]

62. Medzhitov, R. Recognition of Microorganisms and Activation of the Immune Response. Nature 2007, 449, 819-826. [CrossRef]

63. Mangalmurti, N.; Hunter, C.A. Cytokine Storms: Understanding COVID-19. Immunity 2020, 53, 19-25. [CrossRef]

64. Harker, J.A.; Lewis, G.M.; Mack, L.; Zuniga, E.I. Late Interleukin-6 Escalates T Follicular Helper Cell Responses and Controls a Chronic Viral Infection. Science 2011, 334, 825-829. [CrossRef]

65. Azkur, A.K.; Akdis, M.; Azkur, D.; Sokolowska, M.; van de Veen, W.; Brüggen, M.-C.; O'Mahony, L.; Gao, Y.; Nadeau, K.; Akdis, C.A. Immune Response to SARS-CoV-2 and Mechanisms of Immunopathological Changes in COVID-19. Allergy 2020, 75, 1564-1581. [CrossRef] [PubMed]

66. Engelmann, B.; Massberg, S. Thrombosis as an Intravascular Effector of Innate Immunity. Nat. Rev. Immunol. 2013, 13, 34-45. [CrossRef]

67. Betakova, T.; Kostrabova, A.; Lachova, V.; Turianova, L. Cytokines Induced During Influenza Virus Infection. Curr. Pharm. Des. 2017, 23, 2616-2622. [CrossRef] [PubMed]

68. Iwasaki, A.; Medzhitov, R. Regulation of Adaptive Immunity by the Innate Immune System. Science 2010, 327, 291-295. [CrossRef] [PubMed]

69. Zhou, Y.; Fu, B.; Zheng, X.; Wang, D.; Zhao, C.; Qi, Y.; Sun, R.; Tian, Z.; Xu, X.; Wei, H. Pathogenic T-Cells and Inflammatory Monocytes Incite Inflammatory Storms in Severe COVID-19 Patients. Natl. Sci. Rev. 2020, 7, 998-1002. [CrossRef]

70. Wan, S.; Yi, Q.; Fan, S.; Lv, J.; Zhang, X.; Guo, L.; Lang, C.; Xiao, Q.; Xiao, K.; Yi, Z.; et al. Characteristics of Lymphocyte Subsets and Cytokines in Peripheral Blood of 123 Hospitalized Patients with 2019 Novel Coronavirus Pneumonia (NCP). medRxiv 2020. [CrossRef]

71. Xu, Z.; Shi, L.; Wang, Y.; Zhang, J.; Huang, L.; Zhang, C.; Liu, S.; Zhao, P.; Liu, H.; Zhu, L.; et al. Pathological Findings of COVID-19 Associated with Acute Respiratory Distress Syndrome. Lancet Respir. Med. 2020, 8, 420-422. [CrossRef]

72. Braciale, T.J.; Sun, J.; Kim, T.S. Regulating the Adaptive Immune Response to Respiratory Virus Infection. Nat. Rev. Immunol. 2012, 12, 295-305. [CrossRef]

73. D’Errico, S.; Zanon, M.; Montanaro, M.; Radaelli, D.; Sessa, F.; Di Mizio, G.; Montana, A.; Corrao, S.; Salerno, M.; Pomara, C. More than Pneumonia: Distinctive Features of SARS-Cov-2 Infection. From Autopsy Findings to Clinical Implications: A Systematic Review. Microorganisms 2020, 8, 1642. [CrossRef]

74. Newton, A.H.; Cardani, A.; Braciale, T.J. The Host Immune Response in Respiratory Virus Infection: Balancing Virus Clearance and Immunopathology. Semin. Immunopathol. 2016, 38, 471-482. [CrossRef]

75. Corrao, S.; Gervasi, F.; Di Bernardo, F.; Natoli, G.; Raspanti, M.; Catalano, N.; Argano, C. Immunological Characteristics of Non-Intensive Care Hospitalized COVID-19 Patients: A Preliminary Report. J. Clin. Med. 2021, 10, 849. [CrossRef] [PubMed]

76. Corrao, S.; Gervasi, F.; Di Bernardo, F.; Argano, C. Immune Response Failure in Paucisymptomatic Long-Standing SARS-CoV-2 Spreaders. Clin. Pract. 2021, 11, 151-161. [CrossRef] [PubMed] 
77. Chen, N.; Zhou, M.; Dong, X.; Qu, J.; Gong, F.; Han, Y.; Qiu, Y.; Wang, J.; Liu, Y.; Wei, Y.; et al. Epidemiological and Clinical Characteristics of 99 Cases of 2019 Novel Coronavirus Pneumonia in Wuhan, China: A Descriptive Study. Lancet 2020, 395, 507-513. [CrossRef]

78. Bergsbaken, T.; Fink, S.L.; Cookson, B.T. Pyroptosis: Host Cell Death and Inflammation. Nat. Rev. Microbiol. 2009, 7, 99-109. [CrossRef]

79. Lee, H.-M.; Kim, J.-J.; Kim, H.J.; Shong, M.; Ku, B.J.; Jo, E.-K. Upregulated NLRP3 Inflammasome Activation in Patients with Type 2 Diabetes. Diabetes 2013, 62, 194-204. [CrossRef] [PubMed]

80. Prietl, B.; Treiber, G.; Pieber, T.R.; Amrein, K. Vitamin D and Immune Function. Nutrients 2013, 5, 2502-2521. [CrossRef] [PubMed]

81. Li, W.; Moore, M.J.; Vasilieva, N.; Sui, J.; Wong, S.K.; Berne, M.A.; Somasundaran, M.; Sullivan, J.L.; Luzuriaga, K.; Greenough, T.C.; et al. Angiotensin-Converting Enzyme 2 Is a Functional Receptor for the SARS Coronavirus. Nature 2003, 426, 450-454. [CrossRef] [PubMed]

82. Holick, M.F. Vitamin D Deficiency. N. Engl. J. Med. 2007, 357, 266-281. [CrossRef]

83. Battault, S.; Whiting, S.J.; Peltier, S.L.; Sadrin, S.; Gerber, G.; Maixent, J.M. Vitamin D Metabolism, Functions and Needs: From Science to Health Claims. Eur. J. Nutr. 2013, 52, 429-441. [CrossRef]

84. Adams, J.S.; Rafison, B.; Witzel, S.; Reyes, R.E.; Shieh, A.; Chun, R.; Zavala, K.; Hewison, M.; Liu, P.T. Regulation of the Extrarenal CYP27B1-Hydroxylase. J. Steroid Biochem. Mol. Biol. 2014, 144, 22-27. [CrossRef]

85. Klopot, A.; Hance, K.W.; Peleg, S.; Barsony, J.; Fleet, J.C. Nucleo-Cytoplasmic Cycling of the Vitamin D Receptor in the Enterocytelike Cell Line, Caco-2. J. Cell. Biochem. 2007, 100, 617-628. [CrossRef] [PubMed]

86. Haussler, M.R.; Haussler, C.A.; Jurutka, P.W.; Thompson, P.D.; Hsieh, J.C.; Remus, L.S.; Selznick, S.H.; Whitfield, G.K. The Vitamin D Hormone and Its Nuclear Receptor: Molecular Actions and Disease States. J. Endocrinol. 1997, 154, S57-S73. [PubMed]

87. Charoenngam, N.; Shirvani, A.; Holick, M.F. Vitamin D for Skeletal and Non-Skeletal Health: What We Should Know. J. Clin. Orthop. Trauma 2019, 10, 1082-1093. [CrossRef] [PubMed]

88. Liu, P.T.; Stenger, S.; Li, H.; Wenzel, L.; Tan, B.H.; Krutzik, S.R.; Ochoa, M.T.; Schauber, J.; Wu, K.; Meinken, C.; et al. Toll-like Receptor Triggering of a Vitamin D-Mediated Human Antimicrobial Response. Science 2006, 311, 1770-1773. [CrossRef]

89. Weeres, M.A.; Robien, K.; Ahn, Y.-O.; Neulen, M.-L.; Bergerson, R.; Miller, J.S.; Verneris, M.R. The Effects of 1,25-Dihydroxyvitamin D3 on in Vitro Human NK Cell Development from Hematopoietic Stem Cells. J. Immunol. 2014, 193, 3456-3462. [CrossRef]

90. Ota, K.; Dambaeva, S.; Kim, M.W.-I.; Han, A.-R.; Fukui, A.; Gilman-Sachs, A.; Beaman, K.; Kwak-Kim, J. 1,25-Dihydroxy-Vitamin D3 Regulates NK-Cell Cytotoxicity, Cytokine Secretion, and Degranulation in Women with Recurrent Pregnancy Losses. Eur. J. Immunol. 2015, 45, 3188-3199. [CrossRef]

91. Cantorna, M.T.; Zhao, J.; Yang, L. Vitamin D, Invariant Natural Killer T-Cells and Experimental Autoimmune Disease. Proc. Nutr. Soc. 2012, 71, 62-66. [CrossRef]

92. Gibson, C.C.; Davis, C.T.; Zhu, W.; Bowman-Kirigin, J.A.; Walker, A.E.; Tai, Z.; Thomas, K.R.; Donato, A.J.; Lesniewski, L.A.; Li, D.Y. Dietary Vitamin D and Its Metabolites Non-Genomically Stabilize the Endothelium. PLoS ONE 2015, 10, e0140370. [CrossRef]

93. Andrukhova, O.; Slavic, S.; Zeitz, U.; Riesen, S.C.; Heppelmann, M.S.; Ambrisko, T.D.; Markovic, M.; Kuebler, W.M.; Erben, R.G. Vitamin D Is a Regulator of Endothelial Nitric Oxide Synthase and Arterial Stiffness in Mice. Mol. Endocrinol. 2014, $28,53-64$. [CrossRef]

94. Ma, R.; Deng, X.L.; Du, G.L.; Li, C.; Xiao, S.; Aibibai, Y.; Zhu, J. Active Vitamin D3, 1,25-(OH)2D3, Protects against Macrovasculopathy in a Rat Model of Type 2 Diabetes Mellitus. Genet. Mol. Res. 2016, 15, 1-9. [CrossRef]

95. Kim, D.-H.; Meza, C.A.; Clarke, H.; Kim, J.-S.; Hickner, R.C. Vitamin D and Endothelial Function. Nutrients 2020, 12,575 [CrossRef] [PubMed]

96. Molinari, C.; Uberti, F.; Grossini, E.; Vacca, G.; Carda, S.; Invernizzi, M.; Cisari, C. 1 1 ,25-Dihydroxycholecalciferol Induces Nitric Oxide Production in Cultured Endothelial Cells. Cell. Physiol. Biochem. 2011, 27, 661-668. [CrossRef] [PubMed]

97. Corrao, S.; Bocchio, R.M.; Lo Monaco, M.; Natoli, G.; Cavezzi, A.; Troiani, E.; Argano, C. Does Evidence Exist to Blunt Inflammatory Response by Nutraceutical Supplementation during COVID-19 Pandemic? An Overview of Systematic Reviews of Vitamin D, Vitamin C, Melatonin, and Zinc. Nutrients 2021, 13, 1261. [CrossRef] [PubMed]

98. Grant, W.B.; Lahore, H.; McDonnell, S.L.; Baggerly, C.A.; French, C.B.; Aliano, J.L.; Bhattoa, H.P. Evidence That Vitamin D Supplementation Could Reduce Risk of Influenza and COVID-19 Infections and Deaths. Nutrients 2020, 12, 988. [CrossRef] [PubMed]

99. Amento, E.P.; Bhalla, A.K.; Kurnick, J.T.; Kradin, R.L.; Clemens, T.L.; Holick, S.A.; Holick, M.F.; Krane, S.M. 1 Alpha,25Dihydroxyvitamin D3 Induces Maturation of the Human Monocyte Cell Line U937, and, in Association with a Factor from Human T Lymphocytes, Augments Production of the Monokine, Mononuclear Cell Factor. J. Clin. Investig. 1984, 73, 731-739. [CrossRef]

100. Hewison, M. Vitamin D and the Intracrinology of Innate Immunity. Mol. Cell. Endocrinol. 2010, 321, 103-111. [CrossRef]

101. Tang, J.; Zhou, R.; Luger, D.; Zhu, W.; Silver, P.B.; Grajewski, R.S.; Su, S.-B.; Chan, C.-C.; Adorini, L.; Caspi, R.R. Calcitriol Suppresses Antiretinal Autoimmunity through Inhibitory Effects on the Th17 Effector Response. J. Immunol. 2009, 182, 4624-4632. [CrossRef]

102. Chen, S.; Sims, G.P.; Chen, X.X.; Gu, Y.Y.; Chen, S.; Lipsky, P.E. Modulatory Effects of 1,25-Dihydroxyvitamin D3 on Human B Cell Differentiation. J. Immunol. 2007, 179, 1634-1647. [CrossRef] 
103. Lemire, J.M.; Adams, J.S.; Sakai, R.; Jordan, S.C. 1 Alpha,25-Dihydroxyvitamin D3 Suppresses Proliferation and Immunoglobulin Production by Normal Human Peripheral Blood Mononuclear Cells. J. Clin. Investig. 1984, 74, 657-661. [CrossRef]

104. Geldmeyer-Hilt, K.; Heine, G.; Hartmann, B.; Baumgrass, R.; Radbruch, A.; Worm, M. 1,25-Dihydroxyvitamin D3 Impairs NF-KB Activation in Human Naïve B Cells. Biochem. Biophys. Res. Commun. 2011, 407, 699-702. [CrossRef]

105. Heine, G.; Niesner, U.; Chang, H.-D.; Steinmeyer, A.; Zügel, U.; Zuberbier, T.; Radbruch, A.; Worm, M. 1,25-Dihydroxyvitamin D(3) Promotes IL-10 Production in Human B Cells. Eur. J. Immunol. 2008, 38, 2210-2218. [CrossRef] [PubMed]

106. Shirakawa, A.-K.; Nagakubo, D.; Hieshima, K.; Nakayama, T.; Jin, Z.; Yoshie, O. 1,25-Dihydroxyvitamin D3 Induces CCR10 Expression in Terminally Differentiating Human B Cells. J. Immunol. 2008, 180, 2786-2795. [CrossRef] [PubMed]

107. Yamamoto, E.A.; Nguyen, J.K.; Liu, J.; Keller, E.; Campbell, N.; Zhang, C.-J.; Smith, H.R.; Li, X.; Jørgensen, T.N. Low Levels of Vitamin D Promote Memory B Cells in Lupus. Nutrients 2020, 12, 291. [CrossRef] [PubMed]

108. Channappanavar, R.; Perlman, S. Pathogenic Human Coronavirus Infections: Causes and Consequences of Cytokine Storm and Immunopathology. Semin. Immunopathol. 2017, 39, 529-539. [CrossRef]

109. Luk, A.O.Y.; Lau, E.S.H.; Cheung, K.K.T.; Kong, A.P.S.; Ma, R.C.W.; Ozaki, R.; Chow, F.C.C.; So, W.-Y.; Chan, J.C.N. Glycaemia Control and the Risk of Hospitalisation for Infection in Patients with Type 2 Diabetes: Hong Kong Diabetes Registry. Diabetes Metab. Res. Rev. 2017, 33, e2923. [CrossRef]

110. Luk, A.O.Y.; Wu, H.; Lau, E.S.H.; Yang, A.; So, W.-Y.; Chow, E.; Kong, A.P.S.; Hui, D.S.C.; Ma, R.C.W.; Chan, J.C.N. Temporal Trends in Rates of Infection-Related Hospitalisations in Hong Kong People with and without Diabetes, 2001-2016: A Retrospective Study. Diabetologia 2021, 64, 109-118. [CrossRef]

111. Geerlings, S.E.; Hoepelman, A.I. Immune Dysfunction in Patients with Diabetes Mellitus (DM). FEMS Immunol. Med. Microbiol. 1999, 26, 259-265. [CrossRef]

112. Peleg, A.Y.; Weerarathna, T.; McCarthy, J.S.; Davis, T.M.E. Common Infections in Diabetes: Pathogenesis, Management and Relationship to Glycaemic Control. Diabetes Metab. Res. Rev. 2007, 23, 3-13. [CrossRef]

113. Geerlings, S.E.; Brouwer, E.C.; Van Kessel, K.C.; Gaastra, W.; Stolk, R.P.; Hoepelman, A.I. Cytokine Secretion Is Impaired in Women with Diabetes Mellitus. Eur. J. Clin. Investig. 2000, 30, 995-1001. [CrossRef]

114. Price, C.L.; Hassi, H.O.S.A.; English, N.R.; Blakemore, A.I.F.; Stagg, A.J.; Knight, S.C. Methylglyoxal Modulates Immune Responses: Relevance to Diabetes. J. Cell. Mol. Med. 2010, 14, 1806-1815. [CrossRef]

115. Joshi, N.; Caputo, G.M.; Weitekamp, M.R.; Karchmer, A.W. Infections in Patients with Diabetes Mellitus. N. Engl. J. Med. 1999, 341, 1906-1912. [CrossRef] [PubMed]

116. Corrao, S.; Nobili, A.; Natoli, G.; Mannucci, P.M.; Perticone, F.; Pietrangelo, A.; Argano, C.; REPOSI Investigators. Hyperglycemia at Admission, Comorbidities, and in-Hospital Mortality in Elderly Patients Hospitalized in Internal Medicine Wards: Data from the RePoSI Registry. Acta Diabetol. 2021, 58, 1225-1236. [CrossRef] [PubMed]

117. Yoshinaga, R.; Ishikawa, S.; Ayukawa, K.; Doi, Y. Plasma Glucose Level as a Predictor of In-Hospital Mortality in Patients at an Emergency Room: A Retrospective Cohort Study. Diabetes Care 2019, 42, e6-e7. [CrossRef] [PubMed]

118. Das, S.; Anu, K.R.; Birangal, S.R.; Nikam, A.N.; Pandey, A.; Mutalik, S.; Joseph, A. Role of comorbidities like diabetes on severe acute respiratory syndrome coronavirus-2: A review. Life Sci. 2020, 258, 118202. [CrossRef]

119. Roberts, J.; Pritchard, A.L.; Treweeke, A.T.; Rossi, A.G.; Brace, N.; Cahill, P.; MacRury, S.M.; Wei, J.; Megson, I.L. Why Is COVID-19 More Severe in Patients with Diabetes? The Role of Angiotensin-Converting Enzyme 2, Endothelial Dysfunction and the Immunoinflammatory System. Front. Cardiovasc. Med. 2020, 7, 629933. [CrossRef]

120. Reily, C.; Stewart, T.J.; Renfrow, M.B.; Novak, J. Glycosylation in Health and Disease. Nat. Rev. Nephrol. 2019, 15, 346-366. [CrossRef]

121. Varki, A. Sialic Acids in Human Health and Disease. Trends Mol. Med. 2008, 14, 351-360. [CrossRef]

122. Ganz, T.; Nemeth, E. Hepcidin and Iron Homeostasis. Biochim. Biophys. Acta 2012, 1823, 1434-1443. [CrossRef]

123. American Diabetes Association. Classification and Diagnosis of Diabetes. Diabetes Care 2017, 40, S11-S24. [CrossRef] [PubMed]

124. Yang, J.K.; Feng, Y.; Yuan, M.Y.; Yuan, S.Y.; Fu, H.J.; Wu, B.Y.; Sun, G.Z.; Yang, G.R.; Zhang, X.L.; Wang, L.; et al. Plasma Glucose Levels and Diabetes Are Independent Predictors for Mortality and Morbidity in Patients with SARS. Diabet. Med. 2006, 23, 623-628. [CrossRef]

125. Rapozzi, V.; Juarranz, A.; Habib, A.; Ihan, A.; Strgar, R. Is Haem the Real Target of COVID-19? Photodiagn. Photodyn. Ther. 2021, 35, 102381. [CrossRef] [PubMed]

126. Hough, S.; Fausto, A.; Sonn, Y.; Jo, O.K.D.; Birge, S.J.; Avioli, L.V. Vitamin D Metabolism in the Chronic Streptozotocin-Induced Diabetic Rat. Endocrinology 1983, 113, 790-796. [CrossRef] [PubMed]

127. Al Dossari, K.K.; Ahmad, G.; Aljowair, A.; Alqahtani, N.; Shibrayn, M.B.; Alshathri, M.; Alshehri, D.; Akhlaq, S.; Hejab, F.B.; Alqahtani, A.; et al. Association of Vitamin d with Glycemic Control in Saudi Patients with Type 2 Diabetes: A Retrospective Chart Review Study in an Emerging University Hospital. J. Clin. Lab. Anal. 2020, 34, e23048. [CrossRef]

128. Nakashima, A.; Yokoyama, K.; Yokoo, T.; Urashima, M. Role of vitamin D in diabetes mellitus and chronic kidney disease. World J. Diabetes 2016, 7, 89-100. [CrossRef] [PubMed]

129. Tsur, A.; Feldman, B.S.; Feldhammer, I.; Hoshen, M.B.; Leibowitz, G.; Balicer, R.D. Decreased Serum Concentrations of 25-Hydroxycholecalciferol Are Associated with Increased Risk of Progression to Impaired Fasting Glucose and Diabetes. Diabetes Care 2013, 36, 1361-1367. [CrossRef] [PubMed] 
130. Migliaccio, S.; Di Nisio, A.; Mele, C.; Scappaticcio, L.; Savastano, S.; Colao, A. Obesity Programs of nutrition, Education, Research and Assessment (OPERA) Group Obesity and Hypovitaminosis D: Causality or Casualty? Int. J. Obes. Suppl. 2019, 9, 20-31. [CrossRef] [PubMed]

131. Pramono, A.; Jocken, J.W.E.; Essers, Y.P.G.; Goossens, G.H.; Blaak, E.E. Vitamin D and Tissue-Specific Insulin Sensitivity in Humans with Overweight/Obesity. J. Clin. Endocrinol. Metab. 2019, 104, 49-56. [CrossRef] [PubMed]

132. di Filippo, L.; Allora, A.; Doga, M.; Formenti, A.M.; Locatelli, M.; Querini, P.R.; Frara, S.; Giustina, A. Vitamin D Levels Are Associated with Blood Glucose and BMI in COVID-19 Patients, Predicting Disease Severity. J. Clin. Endocrinol. Metab. 2022, 107, e348-e360. [CrossRef]

133. Holick, M.F.; Chen, T.C. Vitamin D Deficiency: A Worldwide Problem with Health Consequences. Am. J. Clin. Nutr. 2008, 87, 1080S-1086S. [CrossRef]

134. Tecilazich, F.; Formenti, A.M.; Giustina, A. Role of Vitamin D in Diabetic Retinopathy: Pathophysiological and Clinical Aspects. Rev. Endocr. Metab. Disord. 2021, 22, 715-727. [CrossRef]

135. Pittas, A.G.; Dawson-Hughes, B.; Sheehan, P.; Ware, J.H.; Knowler, W.C.; Aroda, V.R.; Brodsky, I.; Ceglia, L.; Chadha, C.; Chatterjee, R.; et al. Vitamin D Supplementation and Prevention of Type 2 Diabetes. N. Engl. J. Med. 2019, 381, 520-530. [CrossRef]

136. Chen, X.; Chu, C.; Doebis, C.; von Baehr, V.; Hocher, B. Sex-Dependent Association of Vitamin D with Insulin Resistance in Humans. J. Clin. Endocrinol. Metab. 2021, 106, e3739-e3747. [CrossRef] [PubMed]

137. Price-Haywood, E.G.; Burton, J.; Fort, D.; Seoane, L. Hospitalization and Mortality among Black Patients and White Patients with COVID-19. N. Engl. J. Med. 2020, 382, 2534-2543. [CrossRef] [PubMed]

138. Zhou, Y.; Chi, J.; Lv, W.; Wang, Y. Obesity and Diabetes as High-Risk Factors for Severe Coronavirus Disease 2019 (COVID-19). Diabetes Metab. Res. Rev. 2021, 37, e3377. [CrossRef] [PubMed]

139. Favre, G.; Legueult, K.; Pradier, C.; Raffaelli, C.; Ichai, C.; Iannelli, A.; Redheuil, A.; Lucidarme, O.; Esnault, V. Visceral Fat Is Associated to the Severity of COVID-19. Metabolism 2021, 115, 154440. [CrossRef] [PubMed]

140. Pereira-Santos, M.; Costa, P.R.F.; Assis, A.M.O.; Santos, C.A.S.T.; Santos, D.B. Obesity and Vitamin D Deficiency: A Systematic Review and Meta-Analysis. Obes. Rev. 2015, 16, 341-349. [CrossRef]

141. Monteverdi, S.; Pedersini, R.; Gallo, F.; Maffezzoni, F.; Dalla Volta, A.; Di Mauro, P.; Turla, A.; Vassalli, L.; Ardine, M.; Formenti, A.M.; et al. The Interaction of Lean Body Mass with Fat Body Mass Is Associated with Vertebral Fracture Prevalence in Women with Early Breast Cancer Undergoing Aromatase Inhibitor Therapy. JBMR Plus 2021, 5, e10440. [CrossRef]

142. Formenti, A.M.; Tecilazich, F.; Frara, S.; Giubbini, R.; De Luca, H.; Giustina, A. Body Mass Index Predicts Resistance to Active Vitamin D in Patients with Hypoparathyroidism. Endocrine 2019, 66, 699-700. [CrossRef]

143. Bischoff-Ferrari, H.A.; Dietrich, T.; Orav, E.J.; Dawson-Hughes, B. Positive Association between 25-Hydroxy Vitamin D Levels and Bone Mineral Density: A Population-Based Study of Younger and Older Adults. Am. J. Med. 2004, 116, 634-639. [CrossRef]

144. Yisak, H.; Ewunetei, A.; Kefale, B.; Mamuye, M.; Teshome, F.; Ambaw, B.; Yitbarek, G.Y. Effects of Vitamin D on COVID-19 Infection and Prognosis: A Systematic Review. Risk Manag. Healthc. Policy 2021, 14, 31-38. [CrossRef]

145. Bouillon, R.; Bikle, D. Vitamin D Metabolism Revised: Fall of Dogmas. J. Bone Miner. Res. 2019, 34, 1985-1992. [CrossRef] [PubMed]

146. Ekwaru, J.P.; Zwicker, J.D.; Holick, M.F.; Giovannucci, E.; Veugelers, P.J. The Importance of Body Weight for the Dose Response Relationship of Oral Vitamin D Supplementation and Serum 25-Hydroxyvitamin D in Healthy Volunteers. PLoS ONE 2014, 9, e111265. [CrossRef] [PubMed]

147. Braun, T.R.; Been, L.F.; Blackett, P.R.; Sanghera, D.K. Vitamin D Deficiency and Cardio-Metabolic Risk in a North Indian Community with Highly Prevalent Type 2 Diabetes. J. Diabetes Metab. 2012, 3, 1-13. [CrossRef] [PubMed]

148. Sabico, S.; Enani, M.A.; Sheshah, E.; Aljohani, N.J.; Aldisi, D.A.; Alotaibi, N.H.; Alshingetti, N.; Alomar, S.Y.; Alnaami, A.M.; Amer, O.E.; et al. Effects of a 2-Week 5000 IU versus 1000 IU Vitamin D3 Supplementation on Recovery of Symptoms in Patients with Mild to Moderate Covid-19: A Randomized Clinical Trial. Nutrients 2021, 13, 2170. [CrossRef]

149. Limonte, C.P.; Zelnick, L.R.; Ruzinski, J.; Hoofnagle, A.N.; Thadhani, R.; Melamed, M.L.; Lee, I.-M.; Buring, J.E.; Sesso, H.D.; Manson, J.E.; et al. Effects of Long-Term Vitamin D and n-3 Fatty Acid Supplementation on Inflammatory and Cardiac Biomarkers in Patients with Type 2 Diabetes: Secondary Analyses from a Randomised Controlled Trial. Diabetologia 2021, 64, $437-447$. [CrossRef]

150. Miao, J.; Bachmann, K.N.; Huang, S.; Su, Y.R.; Dusek, J.; Newton-Cheh, C.; Arora, P.; Wang, T.J. Effects of Vitamin D Supplementation on Cardiovascular and Glycemic Biomarkers. J. Am. Heart Assoc. 2021, 10, e017727. [CrossRef] 